\title{
Thyroid dysfunction in sea bass (Dicentrarchus labrax): Underlying mechanisms and effects of polychlorinated biphenyls on thyroid hormone physiology and metabolism
}

\author{
Joseph G. Schnitzler ${ }^{\mathrm{a}, *}$, Niko Celis ${ }^{\mathrm{b}}$, Peter H.M. Klaren ${ }^{\mathrm{c}}$, Ronny Blust ${ }^{\mathrm{b}}$, Alin C. Dirtu ${ }^{\mathrm{d}, \mathrm{e}}$, \\ Adrian Covaci ${ }^{\text {b,d }}$, Krishna Das ${ }^{\text {a }}$ \\ a Mare Centre, Laboratory for Oceanology B6c, Liège University, Liège, Belgium \\ b Laboratory of Ecophysiology, Biochemistry and Toxicology, Department of Biology University of Antwerp, B-2020 Antwerp, Belgium \\ ' Radboud Univ Nijmegen, Inst Water Wetland Res, Fac Sci, Dept Anim Physiol, Heyendaalseweg 135, NL-6525 AJ Nijmegen, The Netherlands \\ d Toxicological Center, University of Antwerp, B-2610 Wilrijk-Antwerp, Belgium \\ e Department of Chemistry, "Al. I. Cuza" University of Iasi, 700506 Iasi, Romania
}

\section{A R T I C L E I N F O}

\section{Article history:}

Received 1 June 2011

Received in revised form 26 July 2011

Accepted 29 July 2011

\section{Keywords:}

Dicentrarchus labrax

Polychlorinated biphenyls

Thyroid hormones

Deiodination

Glucuronidation

Sulfation

In vivo exposure

\begin{abstract}
A B S T R A C T
The current study examines the effect of subchronic exposure to a mixture of Aroclor standards on thyroid hormone physiology and metabolism in juvenile sea bass. The contaminant mixture was formulated to reflect the persistent organic pollution to which the European sea bass population could conceivably be exposed ( $0.3,0.6$ and $1.0 \mu \mathrm{g} \Sigma$ 7PCBs per g food pellets) and higher ( $10 \mu \mathrm{g} \Sigma$ 7PCBs per g food pellets). After 120 days of exposure, histomorphometry of thyroid tissue, muscular thyroid hormone concentration and activity of enzymes involved in metabolism of thyroid hormones were assessed. Mean concentrations of $8,86,142,214$ and $2279 \mathrm{ng} \mathrm{g}^{-1} \mathrm{ww}$ ( $\Sigma 7$ ICES PCB congeners) were determined after 120 days exposure. The results show that the effects of PCB exposures on the thyroid system are dose-dependent. Exposure to environmentally relevant doses of $\mathrm{PCB}(0.3-1.0 \mu \mathrm{g} \Sigma$ 7PCBs per g food pellets $)$ induced a larger variability of the follicle diameter and stimulated hepatic $\mathrm{T}_{4}$ outer ring deiodinase. Muscular thyroid hormone levels were preserved thanks to the PCB induced changes in $\mathrm{T}_{4}$ dynamics. At 10 times higher concentrations ( $10 \mu \mathrm{g} \Sigma$ 7PCBs per g food pellets) an important depression of $\mathrm{T}_{3}$ and $\mathrm{T}_{4}$ levels could be observed which are apparently caused by degenerative histological changes in the thyroid tissue.
\end{abstract}

(C) 2011 Elsevier B.V. All rights reserved.

\section{Introduction}

In a recent field study we have established correlations between exposure to organochlorine contaminants and thyroid function in wild sea bass from European coasts (Schnitzler et al., 2011a). Multivariate statistical analysis specifically revealed the involvement of higher chlorinated PCBs in thyroid dysfunction. Indeed, fishes with higher PCB concentrations displayed alterations in metabolic pathways, viz. deiodination and sulfation, that affect circulating and tissue thyroid hormone levels (Schnitzler et al., 2011a).

The mechanisms of how endocrine disruptors alter thyroid function have been extensively investigated but are still not fully understood. The regulatory pathways involved in thyroid

\footnotetext{
* Corresponding author.

E-mail addresses: joseph.schnitzler@ulg.ac.be (J.G. Schnitzler), Niko.Celis@ua.ac.be (N. Celis), p.klaren@science.ru.nl (P.H.M. Klaren), ronny.blust@ua.ac.be (R. Blust), alindirtu@yahoo.com (A.C. Dirtu), adrian.covaci@ua.ac.be (A.Covaci), krishna.das@ulg.ac.be (K. Das).
}

homeostasis are numerous and complex. As a consequence environmental chemicals can act at many levels in the thyroid system (Ishihara et al., 2003). There are at least three independent, but possibly interacting, mechanisms that may explain the ability of PCB to reduce circulating and tissue levels of thyroid hormones. First, PCBs have been shown to change thyroid gland structure, possibly directly interfering with thyroid gland function (Collins and Capen, 1980b) and disrupting directly the hormone synthesis in the thyroid gland (Boas et al., 2006; Brown et al., 2004a; Ishihara et al., 2003). PCBs may directly interfere with the ability of the thyroid gland to synthesize thyroid hormones by altering mechanisms involved in active accumulation of iodide and proteolysis of thyroglobulin. Second, PCBs can target thyroid hormone metabolism. They may affect extrathyroidal iodothyronine deiodinases, enzymes that control the conversion of thyroid hormones and are thus essential in the regulation of levels of biologically active $T_{3}$ locally and systemically (Ishihara et al., 2003; Zoeller and Tyl, 2007). It has been shown that PCB exposure increases bile flow rate as well as the biliary excretion of $\mathrm{T}_{4}$ (Collins and Capen, 1980a). PCB exposure also induces the expression and activity of 
the phase-II enzymes glucuronosyltransferase and sulfotransferase that also utilize thyroid hormones as conjugate group acceptors and increase $\mathrm{T}_{4}$ conjugation (Klaassen and Hood, 2001; Visser et al., 1993). These actions facilitate $T_{4}$ clearance by hepatic metabolism, reducing the biological half-life of $\mathrm{T}_{4}$. Finally, $\mathrm{PCBs}$ competitively bind to thyroid hormone binding proteins like transthyretin (TTR) in blood (Boas et al., 2006; Ishihara et al., 2003; Wade et al., 2002) and can potentially displace thyroid hormones from their carrier molecules. Moreover, these may interact to produce summative effects. Besides these direct effects, indirect effects via disruption of thyroid hormone receptors and accessory proteins that directly control the gene expression through thyroid hormone responsive elements can also interfere with the thyroid system (Blanton and Specker, 2007; Ishihara et al., 2003).

Disruption of thyroid function can have severe consequences as thyroid hormones play an important role in the maintenance of a normal physiological status in vertebrates. In adult fish, thyroid hormones are of primary importance in the regulation of such fundamental physiological processes as growth, nutrient utilization, and reproduction. Fish grow faster and are healthier when thyroid hormone levels are adequate (Power et al., 2001; Yamano, 2005), providing an economic rationale to study thyroid disruptors in a fishery and aquaculture context. This explains our choice of the test species, European sea bass (Dicentrarchus labrax), as it is an important commercial species, top predator of a simple food web, commonly found in European coastal waters, and with a well documented biology (Loizeau et al., 2001; Pickett and Pawson, 1994).

Polychlorinated biphenyls have been shown to alter thyroid hormone levels in experimental animals, including fish (Brouwer et al., 1989/7; Coimbra and Reis-Henriques, 2007; Collins and Capen, 1980a,b; Fowles et al., 1997; Hallgren, 2001, 2002; Iwanowicz et al., 2009). Most studies on fish thyroidology have involved ambient concentrations of xenobiotics delivered at sublethal, concentrations that, however, are still higher than those encountered in the field (Blanton and Specker, 2007; Brown et al., 2004a). Our study aimed to gain an integrated insight into the effects of a 4month in vivo exposure to various environmentally relevant doses of commercial mixtures of polychlorinated biphenyls (PCBs) on the thyroid system of $D$. labrax. Several endpoints were analyzed simultaneously: thyroid gland histology, hepatic 5'-deiodination (or outer ring deiodination, ORD) activities that convert the thyroid prohormone $T_{4}$ to the bioactive hormone $T_{3}$, and muscular $\mathrm{T}_{4}$ and $\mathrm{T}_{3}$ levels. In addition, two biochemical pathways, i.e. sulfation and glucuronidation, involved in thyroid hormone metabolism and phase- 2 response to toxicants, were assayed. This approach allowed us to determine underlying mechanisms and dose dependency of the effects of these pollutants on the thyroid system of these fish, and to examine the consequences of a potential disruption of the thyroid system on growth performance and condition factor in these commercially important fish species.

\section{Methods}

\subsection{Food preparation}

The contaminant mixture was formulated to reflect the persistent organic pollution to which the European sea bass population could conceivably be exposed. Our previous field study on sea bass from European coastal regions revealed PCB patterns dominated by a large contribution from the hepta-, hexa- and pentachlorinated PCBs (Schnitzler et al., 2011b). These congeners are the most abundant due to their widespread use in commercial mixtures such as Aroclor 1254 and 1260 . We therefore decided to work with a 1:1 mixture of Aroclor 1254 and 1260. Loizeau et al. (2001) caught suprabenthic species (gobies, shrimps and mysidaceans) that are potential prey of sea bass in the Seine estuary (Loizeau, 2001). Based on the reported the PCB concentrations (on dry weight basis with standard deviation), we calculated the $\Sigma$ of the 7 marker PCB congeners (IUPAC nos. 28, 52, 101, 118, 138, 153, 180) presented in Table 1. We contaminated the food with a 1:1 mixture of Aroclor 1254 and 1260 to reach concentrations of the 7 ICES marker congeners ranging from 300 to $1000 \mathrm{ng} \mathrm{g}^{-1}$ food, to reflect best the observed concentration in common sea bass prey.

Aroclor mixtures were added to $100 \mathrm{~mL}$ hexane and $100 \mathrm{-g}$ portions of commercial fish food (T-2P Classic. Trouw. France) into a $1000 \mathrm{~mL}$ round bottom flask. The mixture was slowly stirred by a rotary evaporator (water bath at $60^{\circ} \mathrm{C}$, refrigeration at $5^{\circ} \mathrm{C}$ and pressure at $875 \mathrm{~Pa}$ ) till dryness (ca. $1 \mathrm{~h}$ ). The resulting food spiked with chemicals was then thoroughly dried at $40^{\circ} \mathrm{C}$ overnight. The food pellets kept their initial form and consistency. Control food was prepared in the same manner aside from adding the test mixture.

The concentrations for the $\Sigma 7$ ICES PCB congeners in pellets designed for the five different exposure conditions were measured as described below, and the obtained results are: (1) $27 \mathrm{ng} \mathrm{g}^{-1}$ (assigned label: Control), (2) $329 \mathrm{ng} \mathrm{g}^{-1}$ (assigned the nominal value of $300 \mathrm{ng} \mathrm{g}^{-1} \mathrm{dw}$ ), (3) $629 \mathrm{ngg}^{-1}$ (assigned value $600 \mathrm{ng} \mathrm{g}^{-1} \mathrm{dw}$ ), (4) $1021 \mathrm{ng} \mathrm{g}^{-1}$ (assigned value $1000 \mathrm{ng} \mathrm{g}^{-1} \mathrm{dw}$ ) and (5) $11,395 \mathrm{ng} \mathrm{g}^{-1}$ (assigned value $10,000 \mathrm{ng} \mathrm{g}^{-1} \mathrm{dw}$ ). The correlation factor between nominal and effective concentrations is 0.9999 (Table 1 ).

\subsection{Husbandry}

Experimental trials were conducted in the Biology Department of Antwerp University, Belgium. Seventy-five juvenile sea bass ( $D$. labrax, L.) were obtained from a commercial fish farm (Ecloserie marine de Gravelines, Gravelines, France). Their body mass ranged from 7 to $20 \mathrm{~g}$ (mean $13.2 \pm 2.8 \mathrm{~g}$ ). Fish were housed in 200-L tanks with a natural photoperiod. The water temperature was maintained at $15^{\circ} \mathrm{C}$ during the experiment. Water aeration was set to maintain $100 \%$ air saturation. The water was continuously filtered through mechanical, charcoal and extensive biological filters before being recycled.

Fish were randomly assigned to a control group and four treatment groups (group size $n=15$ in each case) that received contaminated food at $0.3,0.6,1.0$ and $10.0 \mu \mathrm{gg}^{-1}$ ( $\Sigma$ of [7 ICES PCBs] per $g$ of food pellets), respectively. Fish were fed spiked food for 120 days. The daily feeding ration was $2.0 \%$ of the mean body mass of the fish, adjusted after each sampling period based on mean weight of the sub-sample fish that were sacrificed. Feed was presented by sprinkling at the surface of the water and was generally completely consumed by each group of fish within $1 \mathrm{~min}$. Five fish were sampled from each tank on days 40,80 and 120. Fish were always sampled $24 \mathrm{~h}$ after the previous feeding. Weight and length were measured and the specific growth rate $(\mathrm{SGR}=100 \% \times($ ln final weight $-\ln$ initial weight $) /$ total days $)$ and condition factor $\left(\mathrm{CF}=\right.$ weight $\times 100 /$ length $\left.^{3}\right)$ were calculated. The subpharyngeal area was removed and immersed in formalin fixative (VWR International BVBA). Approximately $10 \mathrm{~g}$ of skeletal muscle was excised caudally of the head, dorsal to the lateral line and anterior to the dorsal fin. Muscle and liver samples were frozen immediately on dry ice and stored at $-80^{\circ} \mathrm{C}$ until analysis.

\subsection{Organic contaminant analysis}

\subsubsection{Standards and reagents}

All individual PCB and pesticide standards were obtained from Dr. Ehrenstorfer Laboratories GmbH (Augsburg, Germany). Acetone, $n$-hexane (Hex), dichloromethane, and isooctane were of pesticide-grade (Merck, Germany). Anhydrous sodium sulfate, 
Table 1

Contamination levels for the 7 tracer PCB congeners in current prey of D. labrax and in artificially Arochlor 1254 and 1260 contaminated food. (According to: Loizeau, V., Abarnou, A., Ménesguen, A., 2001. A Steady-State Model of PCB Bioaccumulation in the Sea Bass (Dicentrarchus labrax) Food Web from the Seine Estuary, France Estuaries Vil.24, No 6B, $p$ 1074-1087.).

\begin{tabular}{|c|c|c|c|c|c|c|c|c|c|}
\hline & & 28 & 52 & 101 & 118 & 153 & 138 & 180 & sum 7 PCB \\
\hline \multirow{5}{*}{ Preys } & N. integer & $12.5 \pm 1.4$ & $40.2 \pm 4.2$ & $65.1 \pm 6.6$ & $53.3 \pm 5.4$ & $119.6 \pm 12.0$ & $94.9 \pm 10.0$ & $59.0 \pm 6.0$ & $444.6 \pm 35.1$ \\
\hline & P. microps & $9.3 \pm 1.0$ & $36.5 \pm 3.3$ & $74.6 \pm 7.2$ & $71.5 \pm 6.9$ & $146.5 \pm 15.0$ & $121.5 \pm 12.8$ & $44.0 \pm 4.6$ & $503.9 \pm 48.3$ \\
\hline & P. longirostris & $5.6 \pm 0.6$ & $29.2 \pm 3.1$ & $23.2 \pm 2.0$ & $52.6 \pm 5.4$ & $96.4 \pm 10.0$ & $75.2 \pm 8.1$ & $51.2 \pm 5.3$ & $333.4 \pm 31.3$ \\
\hline & C. crangon & $8.4 \pm 0.5$ & $31.2 \pm 3.3$ & $26.5 \pm 2.1$ & $59.7 \pm 6.1$ & $156.4 \pm 16.0$ & $131.5 \pm 13.6$ & $81.9 \pm 9.0$ & $495.6 \pm 55.8$ \\
\hline & D. labrax & $10.3 \pm 1.5$ & $44.1 \pm 4.8$ & $126.5 \pm 13.0$ & $144.8 \pm 15.0$ & $338.8 \pm 35.0$ & $298.7 \pm 27.1$ & $131.3 \pm 12.7$ & $2397.7 \pm 502,4$ \\
\hline \multirow{5}{*}{ Food } & Control & $5.7 \pm 2.4$ & $10.6 \pm 3.0$ & $4.7 \pm 1.2$ & $1.4 \pm 0.5$ & $2.5 \pm 0.5$ & $1.9 \pm 0.3$ & $0.3 \pm 0.1$ & $27.1 \pm 3.5$ \\
\hline & $0.3 \mu \mathrm{gg}^{-1}$ & $5.7 \pm 0.1$ & $29.8 \pm 0.7$ & $55.6 \pm 0.8$ & $36.2 \pm 0.9$ & $87.3 \pm 3.5$ & $73.0 \pm 2.6$ & $41.2 \pm 1.6$ & $328.8 \pm 27.5$ \\
\hline & $0.6 \mu \mathrm{gg}^{-1}$ & $5.9 \pm 0.6$ & $52.0 \pm 0.1$ & $105.0 \pm 4.0$ & $74.9 \pm 1.6$ & $170.4 \pm 4.5$ & $139.4 \pm 4.4$ & $81.2 \pm 3.3$ & $628.7 \pm 54.7$ \\
\hline & $1.0 \mu \mathrm{gg}^{-1}$ & $10.0 \pm 2.1$ & $79.9 \pm 12.0$ & $167.2 \pm 18.9$ & $121.5 \pm 12.0$ & $278.6 \pm 30.0$ & $226.7 \pm 23.4$ & $136.9 \pm 17.4$ & $1020.8 \pm 89.5$ \\
\hline & $10 \mu \mathrm{gg}^{-1}$ & $82.3 \pm 5.6$ & $825.9 \pm 110.7$ & $1907.6 \pm 219.1$ & $1342.7 \pm 141.2$ & $3106.4 \pm 312.3$ & $2579.8 \pm 263.4$ & $1549.9 \pm 1023.9$ & $11394.6 \pm 1023.9$ \\
\hline
\end{tabular}

basic aluminium oxide, and silica gel (Merck) were used after pre-washing with Hex and heating overnight at $120^{\circ} \mathrm{C}$. An accelerated Soxhlet extractor B-811 (Buchi, Switzerland) was used for the extraction of target compounds from fish tissues and feed.

\subsubsection{Sample preparation and analysis}

A fish fillet was thawed at room temperature, and approximately $1 \mathrm{~g}$ was precisely weighed, ground with $20 \mathrm{~g}$ anhydrous sodium sulfate and placed into an extraction thimble. After addition of internal standards (PCB 46 and PCB 143), the mixture was extracted for $2.5 \mathrm{~h}$ by hot Soxhlet with $80 \mathrm{~mL}$ of hexane/acetone $=3: 1(\mathrm{v} / \mathrm{v})$. The extract was subjected to cleanup on $5 \mathrm{~g}$ of acid silica (44\% sulfuric acid, $\mathrm{w} / \mathrm{w})$. Hexane $(20 \mathrm{~mL})$ was used for the complete elution of PCBs. The final eluate was concentrated under nitrogen until $100 \mu \mathrm{L}$ and transferred to a GC vial.

One $\mu \mathrm{L}$ was injected in pulsed splitless mode on a HewlettPackard 6890 GC connected via direct interface to a HP 5973 mass spectrometer. A $50 \mathrm{~m} \times 0.22 \mathrm{~mm} \times 0.25 \mathrm{~mm}$, HT-8 capillary column (SGE, Zulte, Belgium) was used with helium as carrier gas at a constant flow of $0.7 \mathrm{~mL} / \mathrm{min}$. Injector and interface temperatures were set at 270 and $300^{\circ} \mathrm{C}$, respectively. The oven temperature program began at $90^{\circ} \mathrm{C}$, kept $1 \mathrm{~min}$, and then increased with $15^{\circ} \mathrm{C} / \mathrm{min}$ to $170^{\circ} \mathrm{C}$, held for $3 \mathrm{~min}$, then increased at $4^{\circ} \mathrm{C} / \mathrm{min}$ to $270^{\circ} \mathrm{C}$, held for $1 \mathrm{~min}$, and was further increased at $10^{\circ} \mathrm{C} / \mathrm{min}$ to $290^{\circ} \mathrm{C}$ and held for $15 \mathrm{~min}$. The mass spectrometer was operated in electron impact ionization mode. Two most abundant ions were monitored for each level of chlorination for PCBs. Method limits of detection (LOD) for individual PCB congeners ranged between 0.1 and $0.5 \mathrm{ng} \mathrm{g}^{-1}$ lipid. Recoveries of target compounds ranged between $72 \%$ and $80 \%$. We investigated 38 PCB congeners (IUPAC nos. 18, 31, 28, 52, 49, 47, 44, $74,95,101,99,87,110,118,105,151,149,146,132,153,138,128$, $156,187,183,174,177,171,172,180,170,199,196 / 203,195,194$, 205, 206 and 209) in all 75 muscle samples, and 21 metabolites (IUPAC nos. 4-HO-CB119, 4-HO-CB120, 3HO-CB118, 4HO-CB109, 3HO-CB153, 4HO-CB146, 4HO-CB127, 3НO-CB138, 4HO-CB130, 4HO-CB163, 4HO-CB187, 4-HO-CB162, 4-HO-CB202, 4-HO-CB177, 3HO-CB180, 4HO-CB172, 4HO-CB193, 4-HO-CB198, 4-HO-CB-199, 4-diHO-CB202 and 4-HO-CB208) in five muscle and liver samples.

The method was submitted to regular quality assurance and control procedures. Retention times, ion chromatograms, and intensity ratios of the monitored ions were used as identification criteria. A deviation of the ion intensity ratios within $20 \%$ of the mean values of the calibration standards was considered acceptable. The method performance was assessed through rigorous internal quality control, which included a daily check of calibration curves and regular analysis of procedural blanks and certified reference material CRM 350 (PCBs in mackerel oil). The method was tested by regular participation to interlaboratory tests organized by the US National Institute of Standards and Technology (NIST) for the determination of PCBs in biological samples. The results of the individual PCB congeners deviated less than $20 \%$ from the target values.

\subsection{Thyroid parameters}

\subsubsection{Standards and reagents}

Thyroxine $\left(\mathrm{T}_{4}\right)$, uridine $5^{\prime}$-diphosphate glucuronic acid (UDPGA) and 3'-phospho-adenosine-5'-phosphosulfate (PAPS) were obtained from Sigma Chemical Co. (St. Louis, MO). Sephadex LH-20 was purchased from Amersham Pharmacia Biotech Benelux (Roosendaal, The Netherlands). Outer ring labeled ${ }^{[125} \mathrm{I}^{12} \mathrm{~T}_{4}$ (23.3 TBq/mmol) was obtained from Perkin-Elmer Life Science, Inc. (Boston, MA). All other chemicals were analytical grade and obtained from commercial suppliers. Radiolabeled iodothyronines were purified shortly before use by Sephadex LH-20 column chromatography. Radioactivity was measured in a 1272-Clinigamma gamma counter (LKB/Wallac Oy, Turku, Finland). Protein concentrations were determined using a Coomassie Brilliant Blue G-250 kit (Bio-Rad, München, Germany) and bovine serum albumin as a standard.

\subsubsection{Muscular thyroid hormone determinations}

Muscular total $\mathrm{T}_{3}$ and total $\mathrm{T}_{4}$ concentrations were measured by radio immunoassay (Siemens Coat-a-Count, Brussels, Belgium) according to the manufacturer's instructions. Details of extraction methods and the assay protocol are described elsewhere (Schnitzler et al., 2008). The accuracy of the assay was determined by blind analysis of quality control standards at high, medium and low concentrations. These samples were inserted in duplicate at the front, middle and end of the assay and mean measured concentrations were then compared to actual concentrations to determine assay reliability. The assay was accepted with reliability between 90 and $110 \%$. To determine the efficacy of the extraction process in recovering thyroid hormones as well as transfer of samples into different types of tubes, two recovery systems were used. Unlabelled thyroid hormone was added to the minced fish muscle prior to homogenization. The samples were then subjected to the same homogenization, extraction, reconstitution and thyroid hormone assay procedures as the unknown and standard curve samples. The percentage of thyroid hormone recovered from each spiked tube was calculated and revealed quantitative recoveries of $92 \% \mathrm{~T}_{4}$ and $93 \% \mathrm{~T}_{3}$.

\subsubsection{Sulfotransferase}

Sulfotransferase activity was measured in duplicate with $\mathrm{T}_{4}$ as the conjugate group acceptor, while PAPS was used as the sulfate group donor. Sulfotransferase activity towards $\mathrm{T}_{4}$ was measured by the incubation of approximately $50 \mu \mathrm{g}$ homogenate protein at $37^{\circ} \mathrm{C}$ for $120 \mathrm{~min}$ in $200 \mu \mathrm{L} 100-\mathrm{mM}$ Na-phosphate buffer and $2 \mathrm{mM}$ EDTA (pH 7.2), $1 \mu \mathrm{M}^{125}$ I-labeled $\mathrm{T}_{4}$ and $50 \mu \mathrm{M}$ PAPS. The reaction 
was terminated with $800 \mu \mathrm{L}$ ice-cold $0.1 \mathrm{M} \mathrm{HCl}$, and the quenched incubate was applied to Sephadex LH-20 minicolumns $(2 \mathrm{~mL}$ of a $10 \%, \mathrm{w} / \mathrm{v}$ suspension) to resolve liberated iodide, water-soluble conjugates and native iodothyronines, respectively, as described in detail previously (van der Heide et al., 2002). Radioiodide activities in the water-soluble fractions were interpreted to have originated from the presence of sulfated iodothyronines. Control incubations in these assays were in the absence of PAPS. Net sulfotransferase activities are expressed as a percentage of the total sum of all fractions of the Sephadex LH-20 chromatograms.

\subsubsection{UDP glucuronyltransferase (UGT)}

UGT activity was measured in duplicate with $\mathrm{T}_{4}$ as the conjugate group acceptor. UDPGA was used as the glucuronosyl group donor. The glucuronidation of $\mathrm{T}_{4}$ was measured by the incubation of $50 \mu \mathrm{g}$ homogenate protein at $37^{\circ} \mathrm{C}$ for $120 \mathrm{~min}$ in $200 \mu \mathrm{L}$ buffer containing $100 \mathrm{mM}$ Tris/ $\mathrm{HCl}$ (pH 7.4), $5 \mathrm{mM} \mathrm{MgCl}_{2}$ and $0.05 \% \mathrm{Brij} 56$ (Polyethylene glycol hexadecyl ether; a colorless nonionic detergent and emulsifier; Sigma-Aldrich), supplemented with $1 \mu \mathrm{M}$ ${ }^{125} \mathrm{I}$-labeled $\mathrm{T}_{4}$ and $5 \mathrm{mM}$ UDPGA. The reaction was quenched with $200 \mu \mathrm{L}$ ice-cold methanol, and the incubate was centrifuged for $10 \mathrm{~min}$ at $1500 \times \mathrm{g}$. To $300 \mu \mathrm{L}$ of the supernatant thus obtained $700 \mu \mathrm{L} 0.1 \mathrm{M} \mathrm{HCl}$ was added, and the mixture was subjected to Sephadex LH-20 column chromatography as described above. Radioiodide activities in the water-soluble fractions were here interpreted to have originated from the presence of glucuronidated iodothyronines. Control incubations were in the absence of UDPGA.

\subsubsection{Outer ring deiodinase (ORD)}

$5^{\prime}$-Deiodinase activities were measured in duplicate as described in detail elsewhere (Klaren et al., 2005). Briefly, $50 \mu \mathrm{g}$ homogenate protein was incubated for $1 \mathrm{~h}$ under saturating substrate conditions of $20 \mu \mathrm{M} \mathrm{T}_{4}$ in $200 \mu \mathrm{L}$ of $100 \mathrm{mM}$ Na-phosphate buffer ( $\mathrm{pH} 7.2$ ). Outer ring labeled $\left[{ }^{125} \mathrm{I}\right] \mathrm{T}_{4}$ was used as a tracer, and was purified on a $10 \%(\mathrm{w} / \mathrm{v})$ Sephadex LH-20 mini-column shortly before use. The reaction was quenched by the addition of $100 \mu \mathrm{L}$ ice-cold $5 \%$ BSA, followed by $500 \mu \mathrm{L}$ ice-cold $10 \%$ TCA, and centrifuged at $1400 \times g\left(15 \mathrm{~min}, 4^{\circ} \mathrm{C}\right)$. To $500 \mu \mathrm{L}$ of the deproteinised supernatant thus obtained an equal volume of $1.0 \mathrm{M} \mathrm{HCl}$ was added, and liberated iodide was separated from the native iodothyronine using Sephadex LH-20 column chromatography. Non-enzymatic outer ring deiodination was determined in the absence of a preparation.

\subsubsection{Thyroid histomorphometric analysis}

The thyroid tissues enclosed in the subpharyngeal area were stored in formalin fixative. The tissue was then decalcified in $5 \%$ formic acid and 5\% formaldehyde for a day and transferred into a sodium sulfate solution for another day. The tissues were dehydrated in a graded series of ethanol before being embedded in paraffin wax. The paraffin blocks were longitudinally sectioned $(8 \mu \mathrm{m})$ through all the thyroid tissues and stained conventionally with haematoxylin-eosin.

Sections were analyzed with a light microscope. Images of 50 randomly selected follicles at 100 times magnification were observed. Thyroid histomorphometry was measured using the Macnification ${ }^{\circledR}$ software (version 1.6.1 Orbicule Enhanced Labs). The different measurements in the thyroid tissue were determined by manually selecting the contours of the follicles in the tissue. The follicle area, perimeter, diameter, length and width of every follicle cross section were measured. The shape of the follicles was described with three dimensionless shape descriptors: roundness, form factor and aspect ratio that were calculated as follows.
- Roundness $=4$ Area $\left(\mu \mathrm{m}^{2}\right) / \pi$ Diameter $^{2}(\mu \mathrm{m})$. A follicle with a maximum roundness value of 1 perfectly resembles a circle.

- Form factor $=4 \pi$ Area $\left(\mu \mathrm{m}^{2}\right) /$ Perimeter $^{2}(\mu \mathrm{m})$. The form factor expresses the evenness of the follicles outline; as its value approaches 1 , the outline resembles a circle.

- Aspect ratio = maximum length $(\mu \mathrm{m}) /$ maximum with $(\mu \mathrm{m})$. The larger the aspect ratio, the more elongated the follicle is; a ratio of 1 corresponds to a perfectly circular follicle.

A selection of thyroid tissue was glutaraldehyde-fixed and then embedded in epoxy resin. Ultra-thin sections were obtained using a diamond knife on a Reichert-Jung ultra-microtome (Ultracut E), contrasted with uranyl acetate (alcoholic solution) and lead citrate, and observed in a Jeol JEM $100-S X$ electron microscope at $80 \mathrm{kV}$ of accelerating voltage.

\subsection{Calculations and statistics}

Mean values \pm standard deviation, (median) and min-max are presented, unless indicated otherwise. Statistical analysis of the data was performed using SPSS for Mac ${ }^{\circledR}$ software (SPSS Inc., version 16.0.2). The Kolmogorov-Smirnoff test was used to test for normality of the statistically treated variables. Treatment group comparisons of the thyroid parameters were done by analysis of variance (ANOVA) to compare means. The relationships between thyroid parameters (follicle histomorphometry, thyroid hormone concentrations and metabolic pathways) and toxicological data were analyzed by correlation tests. Growth curves were compared by a distribution-free statistical methodology. Results were considered significant when $p<0.05$.

\section{Results}

No differences in length, weight and condition factor were found between PCB exposed and control sea bass and no other external sign of adverse effects of PCB exposure could be observed (Fig. 3A). All fish were in excellent condition with a condition factor around $1.18 \pm 0.06$.

The initial average concentrations of PCBs measured in sea bass muscle used in accumulation experiments were close to or lower than the method LOQ (mean concentration of $10 \mathrm{ng} \mathrm{g}^{-1}$ ww $\Sigma 7$ marker PCB congeners). This initial average concentration of PCBs did not change significantly in the muscles of sea bass from the control tank during the experimental period $(p=0.81)$. Also, muscular PCBs concentrations increased not significantly with exposure time in all accumulation experiments $(p>0.05)$ (Fig. 1$)$. The penta, hexa- and hepta-CBs represented $88 \%$ of the PCB congeners and these top ten congeners tended to be found in decreasing abundance, as follows: CB $153>$ CB $180>$ CB $138>$ CB 149>CB $101>$ CB $110>$ CB $95>$ CB $118>$ CB 187 (Fig. 2). The muscular concentrations of the different congeners correlated strongly and with the $\Sigma$ PCBs $(R=0.65-0.99, p<0.001)$, as the contamination mixture was formulated from the same stock solution. As a consequence, congener-specific analysis of effects on thyroid system came out with identical results. We therefore present in the following effect analysis, the correlation between effects and the $\Sigma$ PCBs.

Mean concentrations of 8, 86, 142, 214 and $2279 \mathrm{ng} \mathrm{g}^{-1} \mathrm{ww}$ ( $\Sigma 7$ ICES PCB congeners) were determined after 120 days exposure (Fig. 1). Although PCBs are not readily metabolized by fish (Letcher et al., 2000), we investigated the presence of hydroxylated PCB metabolites in both muscle and liver fish samples collected from highest treatment group. Only a few HO-PCB congeners were identified in liver, but none could be detected in muscle samples. With a mean \pm standard deviation (based on 5 samples analyzed) value of $6.4 \pm 3 \mathrm{ng} \mathrm{g}^{-1}$ of liver, HO-PCBs 


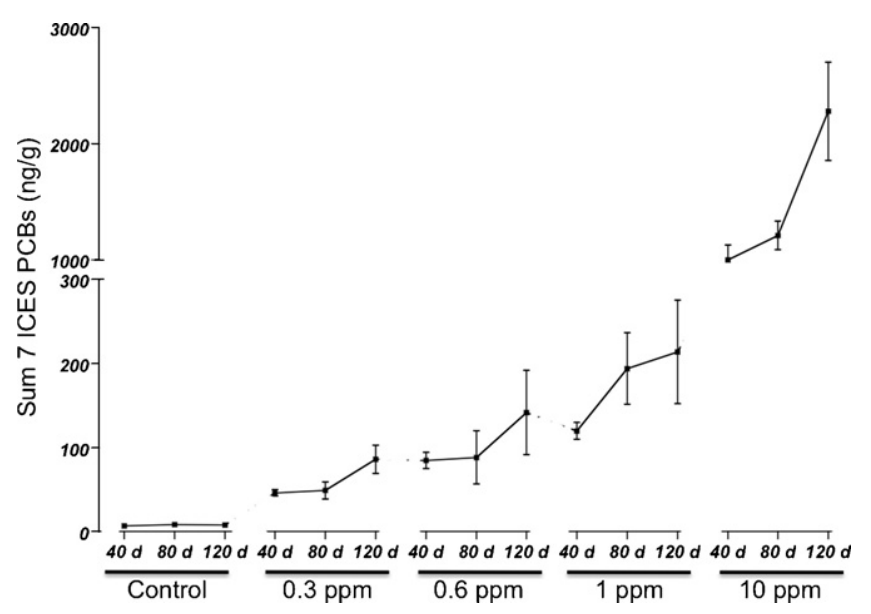

Fig. 1. Bioaccumulation of [7 ICES PCB] in the muscle as a function of time in the different exposure tanks.

consisted of approximately $0.4 \%$ from the sum PCBs measured in the same tissues (data not shown). According to their rank order of concentration, the most abundant metabolites (mainly high-chlorinated ones) were: 4HO-CB187 $>4 \mathrm{HO}-\mathrm{CB} 163>4-\mathrm{HO}-$ CB-199 > 4HO-CB172 > 4HO-CB193 > 4HO-CB146 > 4-HO-CB177. Lower chlorinated PCBs (penta-hexa), despite being dominant in the diet, did not form HO-PCB metabolites at detectable levels in skeletal muscle tissue.

The tested thyroid parameters did not vary significantly between time-points (40,80 and 120 days) indicating that the exposures exert already their effect after 40 days (Fig. 3A-F). The data are therefore pooled by exposure groups, without taking the different time-points into account in Table 2. Muscular $\mathrm{T}_{4}$ concentrations did not change significantly following exposure to contaminated food containing 0.3 up to $1.0 \mu \mathrm{gg}^{-1} \mathrm{dw}$ [7 ICES PCB]. Muscular $T_{3}$ levels had increased 1.5 fold from $0.52 \pm 0.17$ to $0.76 \pm 0.22 \mathrm{ng} \mathrm{g}^{-1}\left(F_{3,56}=3.68, p=0.017, n=60\right)$ in fish fed control and contaminated food $\left(1.0 \mu \mathrm{gg}^{-1} \mathrm{dw}\right.$ [7 ICES PCB]), respectively $(t=-3.26, p=0.003)$. In the case of exposure exceeding the environmentally relevant range $\left(10 \mu \mathrm{g} \mathrm{g}^{-1} \mathrm{dw}\right.$ [ 7 ICES PCB]), lower muscular thyroid hormone concentrations could be observed ( $t=6.58, p<0.001$ and $t=2.03, p=0.045$ for $\mathrm{T}_{4}$ and $\mathrm{T}_{3}$ respectively) compared to control. The $\mathrm{T}_{4}$ and $\mathrm{T}_{3}$ concentration were reduced to $75 \%$ and $30 \%$ compared to controls (Fig. 3B, C, D and Table 1).

The thyroid parameters were not directly related to each other. Correlation test could not identify significant relationships between $\mathrm{T}_{4}, \mathrm{~T}_{3}$ and hepatic deiodinase, sulfotransferase or glucuronyltransferase activity $(p>0.05)$.

A 1.9-fold increase in ORD activity could be observed in fishes with higher contamination levels (Fig. 3E). This observation is supported by the positive correlation between the hepatic ORD activity and the effective $\mathrm{PCB}$ concentration measured in the muscle of these fish $(R=0.414, p<0.001, n=75)$. The activities of conjugating enzymes in liver responded differentially to the PCB exposure. Whereas the glucuronyltransferase (UGT) activity remained unchanged $(R=-0.026, p=0.906, n=55)$, the hepatic sulfotransferase (SULT) activity was maximally reduced to $47 \%$ of its control value. This observation was also supported by a negative correlation between the hepatic sulfotransferase activity and the effective PCB concentration measured in the muscle of these fish $(R=-0.512, p=0.009, n=75)$ (Fig. 3F and Table 1$)$.

Histological examination revealed changes in the thyroid follicles of fishes exposed to $0.3-10 \mu \mathrm{gg}^{-1} \mathrm{dw}$ [7 ICES PCB]). The epithelial cell height ranged from 18 to $31 \mu \mathrm{m}$ and did not vary significantly between the exposure groups $\left(F_{4,21}=1.94, p=0.157\right)$. The mean follicle diameter in the exposure groups ranged between 92 and $121 \mu \mathrm{m}$ and no significant difference could be identified $\left(F_{4,21}=0.34, p=0.897\right)$. A larger heterogeneity of follicle size was observed in thyroids of the 1.0 and $10 \mu \mathrm{gg}^{-1} \mathrm{dw}$ [7 ICES PCB] groups, the standard deviation was 4-6 times higher than in control group and twice as high than in the other exposure groups (0.3 and $0.6 \mu \mathrm{g} \mathrm{g}^{-1} \mathrm{dw}$ [7 ICES PCB]). Thyroids of highly exposed fish (1.0 and $10 \mu \mathrm{gg}^{-1} \mathrm{dw}$ [7 ICES PCB]) contained small follicles $(\varnothing \approx 80 \mu \mathrm{m})$ and very big follicles $(\varnothing \approx 180 \mu \mathrm{m})$. Only slight differences in roundness, form factor and aspect ratio could be identified among the different treatment groups (Table 2). Electron microscopy revealed that cells forming the larger follicles observed in the thyroids of high exposed fish $\left(1.0 \mu \mathrm{g} \mathrm{g}^{-1} \mathrm{dw}\right.$ [7 ICES PCB]), contained extensive lamellar arrays of rough endoplasmic reticulum. There were numerous large electron dense colloid droplets

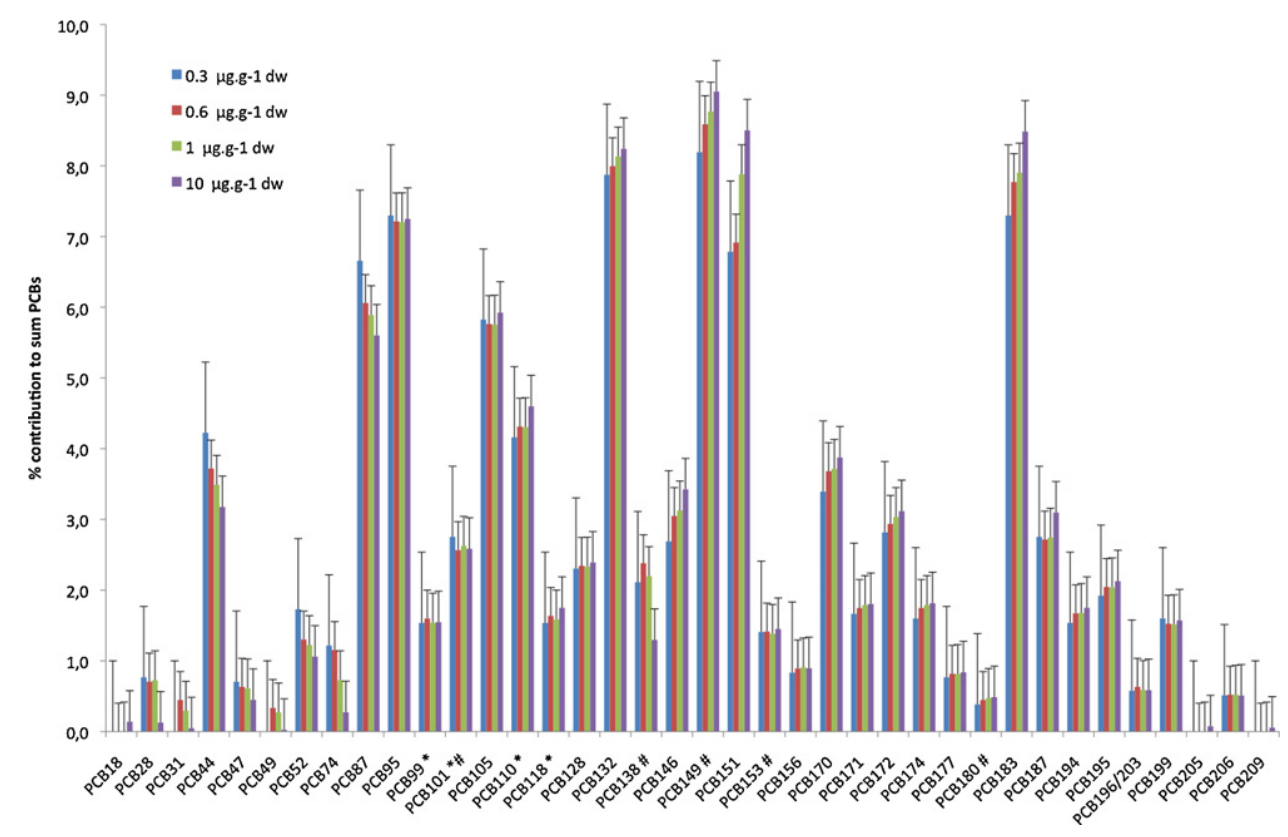

Fig. 2. Distribution of individual $\mathrm{PCB}$ congeners in the muscle of fish from different treatment groups. 
Table 2

Histomorphometric analysis, muscular thyroid hormone levels, mean hepatic metabolic activity and contamination levels in white muscle of European sea bass The concentrations are given in ng g $^{-1}$ wet weight (mean \pm standard deviation, (median) and min-max) ${ }^{*}$ significant ANOVA; ${ }^{a}$ significant after Dunnett's multiple comparisons.

\begin{tabular}{|c|c|c|c|c|c|c|}
\hline Food [7 ICES PCB] & Control & $0.3 \mu \mathrm{gg}^{-1} \mathrm{dw}$ & $0.6 \mu \mathrm{gg}^{-1} \mathrm{dw}$ & $1 \mu g^{-1} \mathrm{dw}$ & $10 \mu \mathrm{gg}^{-1} \mathrm{dw}$ & ANOVA \\
\hline$n$ & 15 & 15 & 15 & 15 & 15 & \\
\hline Sum ICESPCB ( $\left.\mathrm{ng} \mathrm{g}^{-1}\right)$ & $\begin{array}{l}9.9 \pm 10.2 \\
(8.3) \\
3.8-46.9\end{array}$ & $\begin{array}{l}60.4 \pm 30.5 \\
(51.4) \\
23.4-118.6\end{array}$ & $\begin{array}{l}104.8 \pm 76.8 \\
(75.2) \\
46.2-338.5\end{array}$ & $\begin{array}{l}175.9 \pm 99.5 \\
(137.2) \\
79.3-443.1\end{array}$ & $\begin{array}{l}1497.0 \pm 797.3 \\
(1234.5) \\
652.6-3222.3\end{array}$ & $\begin{array}{l}F(4,71)=46.5 \\
p<0.001^{*}\end{array}$ \\
\hline SumPCB $\left(\mathrm{ng} \mathrm{g}^{-1}\right)$ & $\begin{array}{l}31.3 \pm 23.3 \\
(27.1) \\
17.9-117.0\end{array}$ & $\begin{array}{l}156.2 \pm 76.8 \\
(133.4) \\
63.4-301.7\end{array}$ & $\begin{array}{l}268.9 \pm 187.1 \\
(194.3) \\
130.0-835.9\end{array}$ & $\begin{array}{l}441.4 \pm 240.5 \\
(348.4) \\
211.0-1084.1\end{array}$ & $\begin{array}{l}3641.1 \pm 1924.4 \\
(3003.7) \\
1615.2-7840.7\end{array}$ & $\begin{array}{l}F(4,71)=46.1 \\
p<0.001^{*}\end{array}$ \\
\hline $\mathrm{T}_{4}\left(\mathrm{ngg}^{-1}\right)$ & $\begin{array}{l}9.3 \pm 3.6 \\
(9.9) \\
1.1-13.9\end{array}$ & $\begin{array}{l}5.5 \pm 2.7^{\mathrm{a}} \\
(5.4) \\
1.6-11.3\end{array}$ & $\begin{array}{l}10.0 \pm 2.2 \\
(10.5) \\
4.8-13.0\end{array}$ & $\begin{array}{l}9.2 \pm 3.1 \\
(10.3) \\
1.3-13.7\end{array}$ & $\begin{array}{l}2.9 \pm 1.1^{\mathrm{a}} \\
(3.1) \\
0.8-4.6\end{array}$ & $\begin{array}{l}F(4,71)=19.7 \\
p<0.001^{*}\end{array}$ \\
\hline $\mathrm{T}_{3}\left(\mathrm{ng} \mathrm{g}^{-1}\right)$ & $\begin{array}{l}0.52 \pm 0.17 \\
(0.51) \\
0.20-0.80\end{array}$ & $\begin{array}{l}0.56 \pm 0.26 \\
(0.54) \\
0.10-0.90\end{array}$ & $\begin{array}{l}0.66 \pm 0.19 \\
(0.71) \\
0.30-1.01\end{array}$ & $\begin{array}{l}0.76 \pm 0.23^{a} \\
(0.83) \\
0.30-1.10\end{array}$ & $\begin{array}{l}0.40 \pm 0.14^{a} \\
(0.37) \\
0.20-0.70\end{array}$ & $\begin{array}{l}F(4,71)=6.7 \\
p<0.001^{*}\end{array}$ \\
\hline $\begin{array}{l}\text { deiodinase activity } \\
\left(\text { fmol } \mathrm{min}^{-1} \mu \mathrm{g}^{-1} \text { ) }\right.\end{array}$ & $\begin{array}{l}3.8 \pm 2.8 \\
(2.8) \\
0.3-9.3\end{array}$ & $\begin{array}{l}2.8 \pm 2.0 \\
(2.2) \\
0.3-7.0\end{array}$ & $\begin{array}{l}5.4 \pm 3.8 \\
(4.4) \\
0.6-13.0\end{array}$ & $\begin{array}{l}6.4 \pm 2.5^{\mathrm{a}} \\
(5.3) \\
3.1-11.5\end{array}$ & $\begin{array}{l}8.2 \pm 1.3^{a} \\
(7.8) \\
0.8-17.1\end{array}$ & $\begin{array}{l}F(4,71)=7.0 \\
p<0.001^{*}\end{array}$ \\
\hline $\begin{array}{l}\text { sulfatation activity } \\
\left(\text { fmol } \min ^{-1} \mu \mathrm{g}^{-1} \text { ) }\right.\end{array}$ & $\begin{array}{l}3.2 \pm 0.4 \\
(3.2) \\
2.5-3.5\end{array}$ & $\begin{array}{l}3.2 \pm 1.9 \\
(3.5) \\
0.5-5.7\end{array}$ & $\begin{array}{l}2.4 \pm 1.3 \\
(2.7) \\
0.6-3.9\end{array}$ & $\begin{array}{l}1.7 \pm 1.0 \\
(1.7) \\
0.7-2.8\end{array}$ & $\begin{array}{l}1.5 \pm 1.3^{\mathrm{a}} \\
(2.1) \\
0.1-2.5\end{array}$ & $\begin{array}{l}F(4,21)=1.9 \\
p=0.154\end{array}$ \\
\hline $\begin{array}{l}\text { glucuronidation activity } \\
\left(\text { fmol } \min ^{-1} \mu \mathrm{g}^{-1}\right)\end{array}$ & $\begin{array}{l}7.7 \pm 5.2 \\
(7.4) \\
1.2-15.0\end{array}$ & $\begin{array}{l}7.2 \pm 5.7 \\
(6.2) \\
1.3-15.1\end{array}$ & $\begin{array}{l}7.1 \pm 3.1 \\
(7.9) \\
3.4-10.0\end{array}$ & $\begin{array}{l}6.6 \pm 3.2 \\
(6.8) \\
1.4-9.6\end{array}$ & $\begin{array}{l}5.8 \pm 3.2 \\
(6.3) \\
1.4-9.1\end{array}$ & $\begin{array}{l}F(4,21)=1.5 \\
p=0.960\end{array}$ \\
\hline follicle diameter $(\mu \mathrm{m})$ & $\begin{array}{l}92 \pm 5 \\
(92) \\
88-94\end{array}$ & $\begin{array}{l}110 \pm 14 \\
(108) \\
98-126\end{array}$ & $\begin{array}{l}116 \pm 14 \\
(117) \\
103-118\end{array}$ & $\begin{array}{l}121 \pm 21 \\
(120) \\
92-169\end{array}$ & $\begin{array}{l}116 \pm 29 \\
(110) \\
80-180\end{array}$ & $\begin{array}{l}F(4,21)=0.3 \\
p=0.897\end{array}$ \\
\hline cell height $(\mu \mathrm{m})$ & $\begin{array}{l}21 \pm 5 \\
(21) \\
18-25\end{array}$ & $\begin{array}{l}21 \pm 4 \\
(19) \\
19-26\end{array}$ & $\begin{array}{l}22 \pm 3 \\
(22) \\
20-25\end{array}$ & $\begin{array}{l}29 \pm 3 \\
(30) \\
25-31\end{array}$ & $\begin{array}{l}22 \pm 4 \\
(23) \\
18-25\end{array}$ & $\begin{array}{l}F(4,21)=1.9 \\
p=0.157\end{array}$ \\
\hline roundness & $\begin{array}{l}0.81 \pm 0.03 \\
(0.81) \\
0.79-0.83\end{array}$ & $\begin{array}{l}0.73 \pm 0.01 \\
(0.73) \\
0.73-0.75\end{array}$ & $\begin{array}{l}0.77 \pm 0.05 \\
(0.76) \\
0.73-0.83\end{array}$ & $\begin{array}{l}0.74 \pm 0.02 \\
(0.74) \\
0.72-0.75\end{array}$ & $\begin{array}{l}0.75 \pm 0.02 \\
(0.74) \\
0.74-0.77\end{array}$ & $\begin{array}{l}F(4,21)=2.4 \\
p=0.081\end{array}$ \\
\hline form factor & $\begin{array}{l}0.83 \pm 0.02 \\
(0.83) \\
0.82-0.85\end{array}$ & $\begin{array}{l}0.75 \pm 0.02 \\
(0.75) \\
0.72-0.76\end{array}$ & $\begin{array}{l}0.79 \pm 0.04 \\
(0.78) \\
0.76-0.84\end{array}$ & $\begin{array}{l}0.77 \pm 0.01 \\
(0.78) \\
0.76-0.78\end{array}$ & $\begin{array}{l}0.76 \pm 0.03 \\
(0.76) \\
0.74-0.79\end{array}$ & $\begin{array}{l}F(4,21)=3.2 \\
p=0.034^{*}\end{array}$ \\
\hline aspect ratio & $\begin{array}{l}0.98 \pm 0.07 \\
(0.98) \\
0.93-1.03\end{array}$ & $\begin{array}{l}0.94 \pm 0.18 \\
(1.03) \\
0.74-1.06\end{array}$ & $\begin{array}{l}1.01 \pm 0.05 \\
(1.00) \\
0.98-1.06\end{array}$ & $\begin{array}{l}0.99 \pm 0.07 \\
(0.97) \\
0.94-1.08\end{array}$ & $\begin{array}{l}1.23 \pm 0.35 \\
(1.06) \\
1.00-1.65\end{array}$ & $\begin{array}{l}F(4,21)=1.0 \\
p=0.433\end{array}$ \\
\hline
\end{tabular}

similar to that of luminal colloid within follicular cells. Large lysosomal bodies with a heterogeneous internal structure were present in larger numbers than in smaller follicles. The Golgi apparatus and mitochondria are well developed and compressed by the numerous colloid droplets. Long projections of follicular cell cytoplasm often extended from the apical surface into the colloidal lumen (Fig. 4). In the case of exposure exceeding the environmentally relevant range $\left(10 \mu \mathrm{g} \mathrm{g}^{-1} \mathrm{dw}\right.$ [7 ICES PCB]), enlargement of interstitial tissue between follicles and degenerated colloid were observed (Fig. 5).

\section{Discussion}

Our study demonstrates that subchronic exposure to a mixture of PCBs affects thyroid hormone physiology in juvenile sea bass. Clearly, effects of exposure to environmentally relevant concentrations differed in effects and pathways from those observed at higher levels. At lower exposure doses $\left(0.3-0.6 \mu \mathrm{g} \mathrm{g}^{-1} \mathrm{dw}\right.$ [7 ICES $\mathrm{PCB}]$ in food pellets), thyroid hormone homeostasis appeared unaffected while a significant diminution of thyroid hormone levels was observed at higher concentrations.

Environmentally relevant exposures to PCBs affected thyroid hormone metabolism and thyroid hormone synthesis. The histomorphometrical analysis showed a larger variability of the follicle diameter and especially increased epithelial cell heights with higher PCB exposure. The fine structure of fish thyroid gland is more heterogeneous than its mammalian counterpart, containing follicles and cells of different sizes and functional states (Eales, 1979). The mechanisms that generate the marked heterogeneity in follicle architecture in response to contaminants are unknown. Eales (1979) recognized the importance of this heterogeneity of fish thyroid containing both follicles and cells of different sizes and functional states that are hypothesized to go through a histophysiological cycle of generation, maturation and decay (Eales, 1979). Therefore, any minor proliferation of thyroid tissue is fairly difficult to determine. The size of the follicles and the form of the follicular cells gives an indication of the secretory activity of the gland. Thyroids dominated by small follicles lined by cuboid and columnar cells can be classified as highly active. Relatively inactive thyroids show large follicles lined by low or flattened epithelial cells (Hallgren, 2002). Our observations support the hypothesis that the contamination by PCB mixtures induces a hyperactivity of the thyroid tissue indicated by the hypertrophy of follicular epithelial cells. These observations are in accordance with previously reported changes in thyroid histological appearance (Leatherland, 1993; Leatherland and Sonstegard, 1978, 1980; Schnitzler et al., 2008). 

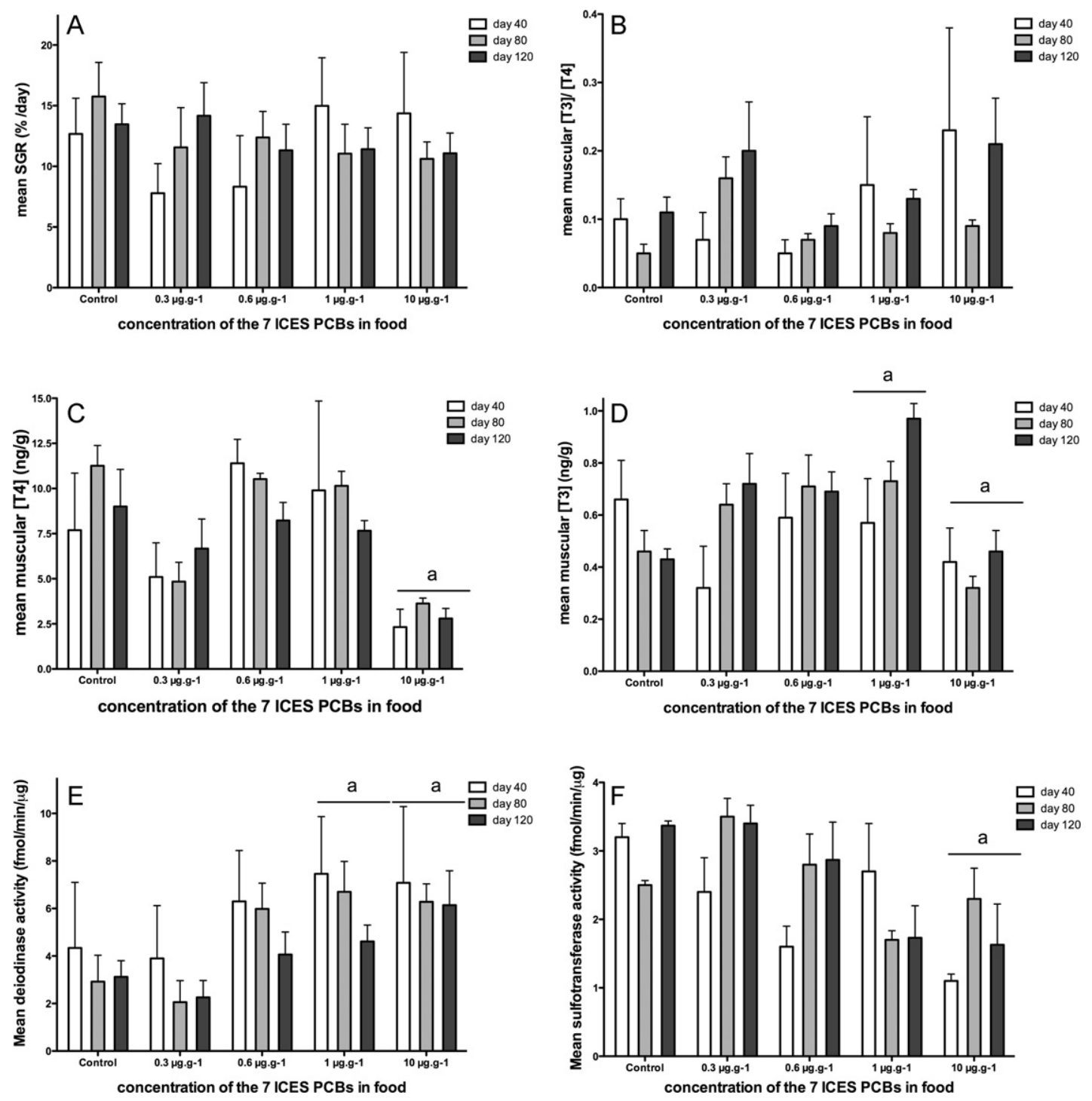

Fig. 3. (A) Mean specific growth rate (\%/day), (B) mean muscular $\left[T_{3}\right] /\left[T_{4}\right]$ ratio, (C) mean muscular $T_{4}$ concentration (ng g ${ }^{-1}$ ), (D) mean muscular $T_{3}$ concentration (ng g ${ }^{-1}$ ), (E) mean deiodinase activity ( $\mathrm{fmol} / \mathrm{min} / \mu \mathrm{g})$ and $\mathrm{F}$ : mean sulfotransferase activity $(\mathrm{fmol} / \mathrm{min} / \mu \mathrm{g})$ as a function of PCB concentration in food and exposure time. The data are given in mean \pm standard deviation; ${ }^{a}$ significantly different from control after Dunnett's multiple comparisons of exposure groups; $n$ per time point is 5 .

The simultaneous presence of small and big follicles in highly exposed fish (1.0 and $10 \mu \mathrm{g} \mathrm{g}^{-1} \mathrm{dw}$ [7 ICES PCB]) indicated an asynchrony of cellular activity in the thyroid gland. The histological ultrastructure of epithelial cells surrounding these bigger follicles was different compared to the smaller follicles, indicating different secretory activities. The organelles in the cytoplasm of these cells were more developed, especially the rough endoplasmic reticulum, probably related to an increased synthesis activity. With regard to the projections of follicular cell cytoplasm from the apical surface into the colloidal lumen, the follicular cells take up colloid droplets by endocytosis. A high number of colloid droplets accumulated noticeably in the cytoplasm of follicular cells. Comparable observations have been made in PCB-fed rats (Capen et al., 1977; Collins and Capen, 1980a,b). Collins and Capen suggested that the lysosomal bodies were unable to interact with colloid droplets in a normal manner, leading to the inhibition of thyroglobulin proteolysis and thyroid hormone release (Collins and Capen, 1980b).

The main metabolic pathways for thyroid hormones are deiodination, glucuronidation and sulfation (Brouwer et al., 1998b; Eales and Brown, 1993). Iodothyronine deiodinase are enzymes involved likewise in the activation of thyroid hormone. In fish, apparently more than in other vertebrates, these important thyroid hormone transformations are controlled outside the thyroid and occur mainly in peripheral tissues (liver, brain, kidney, gill). Fish liver expresses the highest $\mathrm{T}_{4}$ ORD activity, which supports the notion that liver could play a dual role, contributing to both local and systemic supply of $\mathrm{T}_{3}$ (Blanton and Specker, 2007). Exposure of rats to PCBs resulted in an inhibition of hepatic deiodinase activity (Brouwer et al., 1998a; Morse et al., 1996; Visser et al., 1993). Enzymatic outer ring deiodination activities were significantly higher in animals exposed to 1 and $10 \mu \mathrm{g} \mathrm{g}^{-1} \mathrm{dw}$ [7 ICES PCB] in food pellets. This increase was accompanied by an increase in muscular $T_{3}$ in fish exposed to environmental relevant doses of PCB. Adams et al. (2000) examined thyroid hormone deiodination in plaice following short-term exposure to PCB 77 and 126 (Adams et al., 2000). They found that PCB 77 increases the deiodination enzyme activity whereas PCB 126 did not alter $\mathrm{T}_{4} \mathrm{ORD}$ in plaice. These differences in effect may be due to the greater potential for PCB 77 to be hydroxylated (Brouwer et al., 1998b). In mammals, co-planar PCBs generally depressed hepatic $\mathrm{T}_{4}$ ORD (Brouwer et al., 1989/7). Unfortunately, due to the cross-correlation of the different PCBs, it was not possible to differentiate congener-specific effects. It was concluded that 


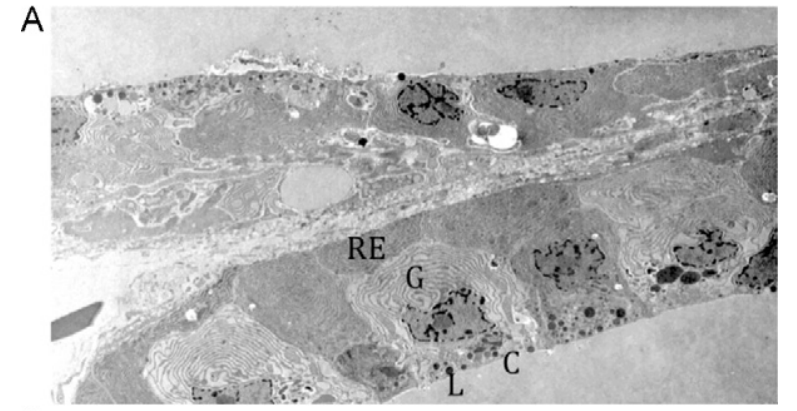

B

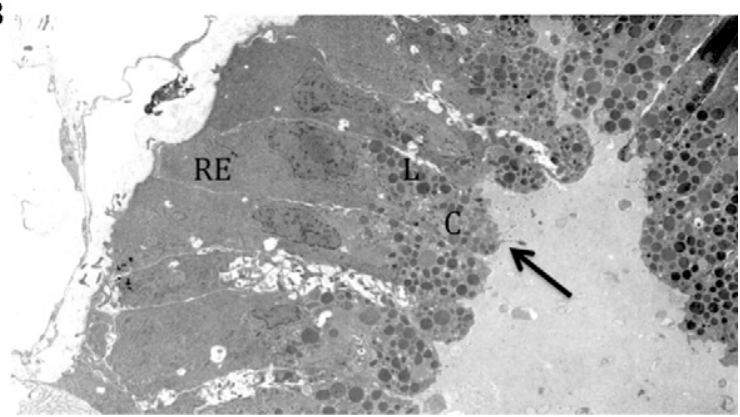

Fig. 4. Thyroid follicular cells of sea bass exposed to $1 \mu \mathrm{gg}^{-1} \Sigma$ [7 PCBs] in food $(\times 2000)$ :

(A) between two smaller follicles, we can see few apical cytoplasmic processes extending into follicular lumen, well developed rough endoplasmic reticulum (RE) and large Golgi apparatuses $(\mathrm{G})$ and few colloid droplets $(\mathrm{C})$ and lysosomal bodies (L)

(B) of large follicle, we can see apical cytoplasmic processes extending into follicular lumen (Arrow), dilated profiles of rough endoplasmic reticulum (RE), numerous large colloid droplets (C) and lysosomal bodies (L).

the PCB-induced changes in deiodinating activity likely represents compensatory responses to disrupting effects that might otherwise have depressed the plasma $\mathrm{T}_{3}$ levels. The different responses between mammalian and fish species rests on the fact that in fish the $\mathrm{T}_{3}$ levels are primarily under peripheral control.

Thyroid hormone conjugation with glucuronic acid inactivates the thyroid hormones, increases their solubility and facilitates their excretion in bile and urine (Brouwer et al., 1998b). In our experiment no effect of PCB exposure on $\mathrm{T}_{4} \mathrm{UGT}$ could be observed, whereas other studies have reported marked induction in rats following exposure to individual PCB congeners (Adams et al., 2000; Brown et al., 2004b; Morse et al., 1993; Spear et al., 1990; Visser et al., 1993) and mixtures (Hood, 1999; Klaassen and Hood, 2001; Morse et al., 1996). In most of these reports reduced $\mathrm{T}_{4}$ levels in the same animal accompanied an increased $\mathrm{T}_{4}$ UGT activity and negative correlations between those two parameters suggested a causal relationship. Generally, phenolic PCBs undergo detoxification by glucuronidation and induce hepatic UGTs to facilitate excretion of PCBs (Klaassen and Hood, 2001; Visser et al., 1993). Although there was no increase in hepatic $\mathrm{T}_{4}$-UGT activity in our experiment. This may be because the $\mathrm{T}_{4}$-glucuronidation enzyme assay does not evaluate activity for specific UGT isoforms. UGT activity induction can be dependent on aryl hydrocarbon receptor (AhR) activation (Richardson et al., 2008). Antagonistic interactions between AhR agonists such as PCB 126 and other AhR-inactive PCBs have been demonstrated (Safe et al., 1998).

Another essential step in metabolism of iodothyronines is the sulfation by sulfotransferases (Schuur et al., 1999). They also inactivate the thyroid hormones, increase their solubility and facilitate their excretion in bile and urine like UGT. Furthermore TH sulfates do not bind to $\mathrm{T}_{3}$ receptors and are thus unable to mimic thyroid hormone activity and are rapidly degraded by inner ring deiodinases (Brouwer et al., 1998b; Schuur et al., 1999). In our experiment we observed a general decrease of SULT activity. This is in accordance with in vitro studies using rat and human hepatoma cell lines that related a strong inhibition of thyroid hormone sulfation with hydroxylated metabolites of PCB (Brouwer et al., 1998b; Schuur et al., 1999). This reduced $\mathrm{T}_{4}$ SULT activity is accompanied by an increase of muscular $\mathrm{T}_{4}$ levels in animals exposed to environmentally relevant doses of PCB.

The heterogeneity of fish thyroid systems and their resilience to perturbations make it difficult to interpret these changes in activity. It is well accepted that some PCB congeners, due to their structural similarity, are able to serve as binding ligands for $\mathrm{T}_{4}$-binding proteins (Darnerud et al., 2001). By these means they reduce thyroid hormone levels by displacing them from transport proteins and increasing their excretion. Both $\mathrm{T}_{4}$ and $\mathrm{T}_{3}$ have a negative feedback effect on TSH secretion by the pituitary in teleost fish species (Yoshiura et al., 1999). That may have stimulated the production of $\mathrm{T}_{4}$, revealed by thyroid histomorphometry. The deiodinase activity was increased, thus more conversion of $T_{4}$ to $T_{3}$, and there is less excretion of thyroid hormones through the hepatic pathway as the sulfation activity decreased with raising PCB exposure. These modifications in thyroid hormone dynamics contribute to maintain thyroid hormone levels in an acceptable range. The PCB induced disruption of thyroid system is countered by an extensive self-regulatory feedback control.

Nevertheless, we observe an important lowering of muscular $\mathrm{T}_{3}$ and $\mathrm{T}_{4}$ levels in animals exposed to $10 \mu \mathrm{gg}^{-1} \mathrm{dw}$ [7 ICES PCBs] in food pellets. This observation indicates that at those exposure levels other causes than the metabolic pathways are involved. In these fishes the histological examination revealed lymphoid cell infiltration and enlargement of the interstitial tissue between follicles and degenerated colloid. The follicles appeared in lower number and the tissue seems disorganized. These degenerative changes might have caused the observed hypothyroidism in these fish. Probably, the pollutants at this dose interfere with the synthesis and secretion of thyroid hormones.

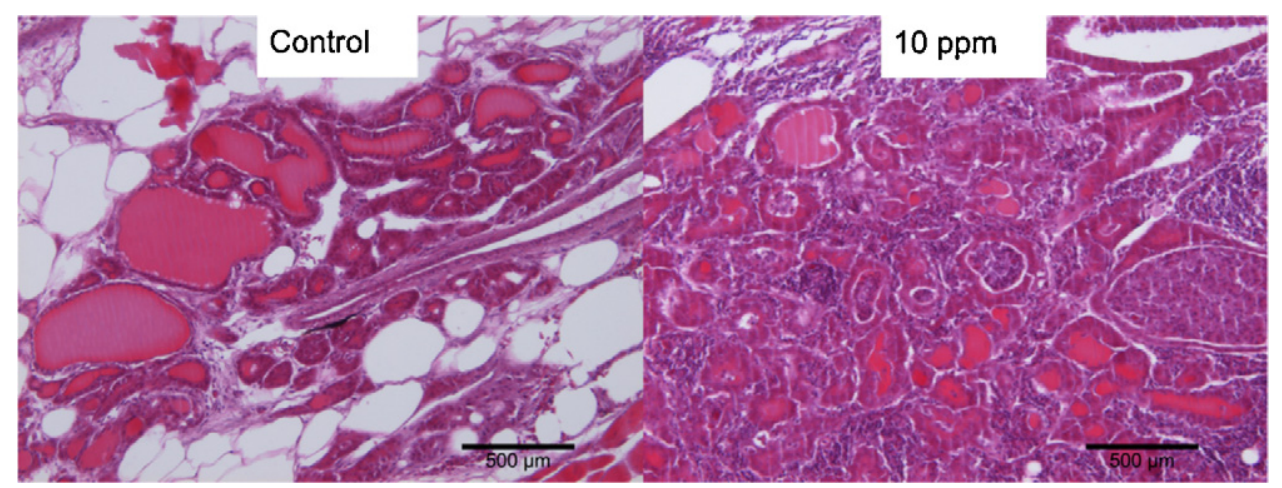

Fig. 5. Thyroid histological section of a control and an exposed sea bass $\left(10 \mu \mathrm{gg}^{-1} \mathrm{dw}\right)$. 
The thyroid status has pronounced effects on growth and development in fish (Blanton and Specker, 2007; Inui et al., 1995; Klaren et al., 2008; Power et al., 2001; Shiao and Hwang, 2006; Yamano, 2005). Depending on the dosage used, $\mathrm{T}_{3}$ supplementation has anabolic and catabolic effects whereas hypothyroidism always results in growth retardation (Theodorakis et al., 2006; Van der Geyten et al., 2001). In this study, neither size nor weight differences could be found between the treatment groups, which can be explained by the high feeding rate of these fishes. Thyroid hormone reserves have not been determined fully in any fish species but based on human values it would seem advisable to continue studies for several months to determine a true measure of effect on the thyroidal status (Brown et al., 2004a).

\section{Conclusions}

The presented results show clearly that the effects of PCB exposures on the thyroid system are dose-dependent. Exposure to environmentally relevant doses of PCB modifies hepatic $\mathrm{T}_{4}$ outer ring deiodinase and induced the hormone synthesis and secretion. Ultrastructural histological investigations showed a potential inhibition of thyroglobulin proteolysis and thyroid hormone release in the thyroids of high exposed fish $\left(1.0 \mu \mathrm{g} \mathrm{g}^{-1} \mathrm{dw}\right.$ [7 ICES PCB]). Meanwhile, the thyroid hormone levels were preserved. The presented mechanisms are part of the extensive autoregulatory feedback control at both central and peripheral levels, and the induced changes in thyroid hormone dynamics keep the levels in an acceptable range. At 10 times higher concentrations, an important depression of muscular $T_{3}$ and $T_{4}$ levels could be observed which are apparently caused by other mechanisms than metabolic pathways. Here we observed degenerative histological changes in the thyroid tissue that might have caused the hypothyroidism in these fish.

\section{Acknowledgements}

Schnitzler, J. received grants from FRIA (Fonds pour la formation à la recherche dans l'industrie et dans l'agriculture). Krishna, D. is a F.R.S. - FNRS Research Associate (Fonds de la Recherche Scientifique). The authors are grateful to Pr. Thomé, JP., and Louvet, M. for their logistical assistance in food pellet preparation. Covaci, A. acknowledges a postdoctoral fellowship from the Research Scientific Foundation of Flanders (FWO). Dirtu, A. acknowledges financial support from UA. This is a MARE publication 213.

\section{References}

Adams, B.A., Cyr, D.G., Eales, J.G., 2000. Thyroid hormone deiodination in tissues of American plaice, Hippoglossoides platessoides: characterization and short-term responses to polychlorinated biphenyls (PCBs) 77 and 126. Comparative Biochemistry and Physiology Part C: Pharmacology, Toxicology and Endocrinology $127,367-378$

Blanton, M.L., Specker, J.L., 2007. The hypothalamic-pituitary-thyroid (HPT) axis in fish and its role in fish development and reproduction. Critical Reviews in Toxicology 37, 97-115.

Boas, M., Feldt-Rasmussen, U., Skakkebaek, N.E., Main, K.M., 2006. Environmental chemicals and thyroid function. European Journal of Endocrinology 154 599-611.

Brouwer, A., Morse, D., Lans, M., Schuur, A., Murk, A., Klasson-Wehler, E., 1998a. Interactions of persistent environmental organohalogens with the thyroid hormone system: mechanisms and possible consequences for animal and human health. Toxicology and Industrial Health 14, 59-84.

Brouwer, A., Morse, D.C., Lans, M.C., Schuur, A.G., Murk, A.J., Klasson-Wehler, E., Bergman, A., Visser, T.J., 1998b. Interactions of Persistent Environmental Organohalogens with the Thyroid Hormone System: Mechanisms and Possible Consequences for Animal and Human Health. Princeton Scientific Publ Inc, pp. 59-84.

Brouwer, A., Reijnders, P.J.H., Koeman, J.H., 1989/7. Polychlorinated biphenyl (PCB)contaminated fish induces vitamin A and thyroid hormone deficiency in the common seal (Phoca vitulina). Aquatic Toxicology 15, 99-105.
Brown, S.B., Adams, B.A., Cyr, D.G., Eales, J.G., 2004a. Contaminant effects on the teleost fish thyroid. Environmental Toxicology and Chemistry 23, 1680-1701.

Brown, S.B., Evans, R.E., Vandenbyllardt, L., Finnson, K.W., Palace, V.P., Kane, A.S. Yarechewski, A.Y., Muir, D.C.G., 2004b. Altered thyroid status in lake trout (Salvelinus namaycush) exposed to co-planar 3,3',4,4',5-pentachlorobiphenyl. Aquatic Toxicology 67, 75-85.

Capen, C.C., Collins, W.T., Kasza, L., 1977. Effects of polychlorobiphenyl (PCB) on fine-structure and function of thyroid-gland in rat. Laboratory Investigation 36 , 332-333.

Coimbra, A., Reis-Henriques, M., 2007. Tilapia larvae Aroclor 1254 exposure: effects on gonads and circulating thyroid hormones during adulthood. Bulletin of Environmental Contamination and Toxicology 79, 488-493.

Collins, W.T., Capen, C.C., 1980a. Biliary excretion of ${ }^{125} \mathrm{I}$-Thyroxine and fine structural alterations in the thyroid of Gunn Rats fed polychlorinated biphenyls (PCB). Laboratory Investigation 43, 158-164.

Collins, W.T., Capen, C.C., 1980b. Fine structural lesions and hormonal alterations in thyroid glands of perinatal rats exposed in utero and by Milk to polychlorinated biphenyls. American Association of Pathologists 99, 125-142.

Darnerud, P.O., Eriksen, G.S., Johannesson, T., Larsen, P.B., Viluksela, M., 2001. Polybrominated diphenyl ethers: occurence, dietary exposure, and toxicology. Environmental Health Perspectives 109, 49-68.

Eales, J.G., 1979. Thyroid function in cyclostomes and fishes. In: Barrington, E.J.(Ed.), Hormones ad Evolution. Academic Press, New York.

Eales, J.G., Brown, S.B., 1993. Measurement and regulation of thyroidal status in teleost fish. Reviews in Fish Biology and Fisheries 3, 299-347.

Fowles, J.R., Fairbrother, A., Trust, K.A., Kerkvliet, N.I., 1997. Effects of Aroclor 1254 on the Thyroid gland, immune function, and hepatic cytochrome P450 activity in mallards. Environmental Research 75, 119-129.

Hallgren, S., 2001. Effects of polybrominated diphenyl ethers (PBDEs) and polychlorinated biphenyls (PCBs) on thyroid hormone and vitamin A levels in rats and mice. Archives of Toxicology 75, 200-208.

Hallgren, S., 2002. Polybrominated diphenyl ethers (PBDEs), polychlorinated biphenyls (PCBs) and chlorinated paraffins (CPs) in rats - testing interactions and mechanisms for thyroid hormone effects. Toxicology 177, 227-243.

Hood, A., 1999. Effects of microsomal enzyme inducers on thyroid-follicular cell proliferation, hyperplasia, and hypertrophy. Toxicology and Applied Pharmacology $160,163-170$

Inui, Y., Yamano, K., Miwa, S., 1995. The role of thyroid hormone in tissue development in metamorphosing flounder. Aquaculture 135, 87-98.

Ishihara, A., Sawatsubashi, S., Yamauchi, K., 2003. Endocrine disrupting chemicals: interference of thyroid hormone binding to transthyretins and to thyroid hormone receptors. Molecular and Cellular Endocrinology 199, 105-117.

Iwanowicz, L.R., Blazer, V.S., McCormick, S.D., VanVeld, P.A., Ottinger, C.A., 2009. Aroclor 1248 exposure leads to immunomodulation, decreased disease resistance and endocrine disruption in the brown bullhead, Ameiurus nebulosus. Aquatic Toxicology 93, 70-82.

Klaassen, C.D., Hood, A.M., 2001. Effects of microsomal enzyme inducers on thyroid follicular cell proliferation and thyroid hormone metabolism. Toxicology and Pathology 29, 34-40.

Klaren, P., Wunderink, Y., Yufera, M., Mancera, J., Flik, G., 2008. The thyroid gland and thyroid hormones in Senegalese sole (Solea senegalensis) during early development and metamorphosis. General and Comparative Endocrinology 155 , 686-694.

Klaren, P.H.M., Haasdijk, R., Metz, J.R., Nitsch, L.M.C., Darras, V.M., Van der Geyten, S., Flik, G., 2005. Characterization of an iodothyronine 5'-deiodinase in gilthead seabream (Sparus auratus) that is inhibited by dithiothreitol. Endocrinology 146, 5621-5630.

Leatherland, J.F., 1993. Field observation on reproductive and developmental dysfunction in introduced and native salmonids from the Great Lakes. Histochemical Journal 19, 737-751.

Leatherland, J.F., Sonstegard, R.A., 1978. Lowering of serum thyroxine and triiodothyronine levels in yearling coho salmon by dietary mirex and PCBs. Journal of Fisheries Research Board, Canada 35, 1285-1289.

Leatherland, J.F., Sonstegard, R.A., 1980. Effect of dietary polychloninated biphenyls (PCBs) or mirex in combination with food deprivation and testosterone administration on serum thyroid hormone concentration and bioaccumulation of organochlorines in rainbow trout, Salmo gairdneri. Journal of Fish Diseases 3 , $115-124$.

Letcher, R.J., Klasson-Wehler, E., Bergman, A., 2000. Methyl sulfone and hydroxylated metabolites of polychlorinated biphenyls. In: New Types of Persistent Halogenated Compounds. Springer-Verlag Berlin, Berlin, pp. 315-359.

Loizeau, V., 2001. A steady-state model of PCB bioaccumulation in the sea bass (Dicentrarchus labrax) food web from the Seine estuary, France. Estuaries 24 , 1074-1087.

Loizeau, V., Abarnou, A., Cugier, P.,Jaouen-Madoulet, A., Le Guellec, A.M., Menesguen, A., 2001. A model of PCB bioaccumulation in the sea bass food web from the seine estuary (Eastern English Channel). Marine Pollution Bulletin 43, 242-255.

Morse, D.C., Groen, D., Veerman, M., Vanamerongen, C.J., Koeter, H., Vanprooije, A.E.S., Visser, T.J., Koeman, J.H., Brouwer, A., 1993. Interference of polychlorinated-biphenyls in hepatic and brain thyroid-hormone metabolism in fetal and neonatal rats. Toxicology and Applied Pharmacology 122, 27-33.

Morse, D.C., Wehler, E.K., Wesseling, W., Koeman, J.H., Brouwer, A., 1996. Alterations in rat brain thyroid hormone status following pre- and postnatal exposure to polychlorinated biphenyls (Aroclor 1254). Toxicology and Applied Pharmacology $136,269-279$. 
Pickett, G.D., Pawson, M.G., 1994. Sea Bass-Biology, Exploitation, and Conservation. Chapman and Hall, London.

Power, D.M., Llewellyn, L., Faustino, M., Nowell, M.A., Björnsson, B.T., Einarsdottir, I.E., Canario, A.V.M., Sweeney, G.E., 2001. Thyroid hormones in growth and development of fish. Comparative Biochemistry and Physiology Part C: Toxicology \& Pharmacology 130, 447-459.

Richardson, V.M., Staskal, D.F., Ross, D.G., Diliberto, J.J., DeVito, M.J., Birnbaum, L.S., 2008. Possible mechanisms of thyroid hormone disruption in mice by BDE 47, a major polybrominated diphenyl ether congener. Toxicology and Applied Pharmacology 226, 244-250.

Safe, S., Wang, F., Porter, W., Duan, R., McDougal, A., 1998. Ah receptor agonists as endocrine disruptors: antiestrogenic activity and mechanisms. Toxicology Letters 103, 343-347.

Schnitzler, J.G., Klaren, P.H.M., Bouquegneau, J.-M., Das, K., 2011a. Environmental factors affecting thyroid function of wild sea bass (Dicentrarchus labrax) from European coasts, Chemosphere, submitted for publication.

Schnitzler,J.G., Koutrakis, E., Siebert, U., Thomé,J.P., Das, K., 2008. Effects of persistent organic pollutants on the thyroid function of the European sea bass (Dicentrarchus labrax) from the Aegean sea, is it an endocrine disruption? Marine Pollution Bulletin 56, 1755-1764

Schnitzler, J.G., Thomé, J.P., Lepage, M., Das, K., 2011b. Organochlorine pesticides and polychlorinated biphenyl residues in wild sea bass (Dicentrarchus labrax) off European estuaries. Science of the Total Environment 409, 3680-3686.

Schuur, A.G., Bergman, Å., Brouwer, A., Visser, T.J., 1999. Effects of pentachlorophenol and hydroxylated polychlorinated biphenyls on thyroid hormone conjugation in a rat and a human hepatoma cell line. Toxicology in Vitro 13, 417-425.

Shiao, J., Hwang, P., 2006. Thyroid hormones are necessary for the metamorphosis of tarpon Megalops cyprinoides leptocephali. Journal of Experimental Marine Biology and Ecology 331, 121-132.
Spear, P.A., Higueret, P., Garcin, H., 1990. Increased thyroxine turnover after $3,3^{\prime}, 4,4^{\prime}, 5,5^{\prime}$-hexabromobiphenyl injection and lack of effect on peripheral triiodothyronine production. Canadian Journal of Physiology and Pharmacology $68,1079-1084$

Theodorakis, C., Rinchard, J., Anderson, T., Liu, F., Park, J.-W., Costa, F., McDaniel, L., Kendall, R., Waters, A., 2006. Perchlorate in fish from a contaminated site in east-central Texas. Environmental Pollution 139, 59-69.

Van der Geyten, S., Toguyeni, A., Baroiller, J.-F., Fauconneau, B., Fostier, A., Sanders, J.P., Visser, T.J., Kühn, E.R., Darras, V.M., 2001. Hypothyroidism induces type I iodothyronine deiodinase expression in Tilapia liver. General and Comparative Endocrinology 124, 333-342.

van der Heide, S., Visser, T., Everts, M., Klaren, P., 2002. Metabolism of thyroid hormones in cultured cardiac fibroblasts of neonatal rats. Journal of Endocrinology 174, 111-119.

Visser, T.J., Kaptein, E., Vantoor, H., Vanraaij, J., Vandenberg, K.J., Joe, C.T.T., Vanengelen, J.G.M., Brouwer, A., 1993. Glucuronidation of thyroid-hormone in rat-liver - effects of in-vivo treatement with microsomal-enzyme inducers and in-vitro assay conditions. Endocrinology 133, 2177-2186.

Wade, M., Parent, S., Finnson, K.W., Foster, W., Younglai, E., McMahon, A., Cyr, D.G., Hughes, C., 2002. Thyroid toxicity due to subchronic exposure to a complex mixture of 16 organochlorines, lead and cadmium. Toxicological Sciences 67, 207-218.

Yamano, K., 2005. The role of thyroid hormone in Fish development with reference to aquaculture. JARQ 39, 161-168.

Yoshiura, Y., Sohn, Y., Munakata, A., Kobayashi, M., Aida, K., 1999. Molecular cloning of the cDNA encoding the beta subunit of thyrotropin and regulation of its gene expression by thyroid hormones in the goldfish, Carassius auratus. Fish Physiology and Biochemistry 21, 201-210.

Zoeller, R.T., Tyl, R.W.S.W.T., 2007. Current and potential rodents screen and tests for thyroid toxicants. Critical Review in Toxicology 37, 55-95. 